\title{
Analiza składu ciała zawodników w trakcie bezpośredniego przygotowania startowego do Głównych Mistrzostw Polski w Pływaniu w 2016 roku
}

\author{
Determination of the body composition of participants during the tapering period prior to the \\ Main Polish Championship in Swimming in 2016
}

\author{
Żaneta Ciosek ${ }^{\circledR}$, Magdalena Ptak¹, Aleksandra Szylińska, Karolina Kot² ${ }^{2}$ Adam Drozd ${ }^{3}$, Hanna Mosiejczuk \\ Elżbieta Baryła-Pankiewicz ${ }^{4}$, Iwona Rotter ${ }^{1}$
}

${ }^{1}$ Pomorski Uniwersytet Medyczny w Szczecinie, Samodzielna Pracownia Rehabilitacji Medycznej, ul. Żołnierska 54, 71-210 Szczecin

${ }^{2}$ Pomorski Uniwersytet Medyczny w Szczecinie, Studenckie Koło Naukowe przy Katedrze i Zakładzie Biologii i Parazytologii Medycznej,

al. Powstańców Wlkp. 72, 70-111 Szczecin

${ }^{3}$ Miejski Ośrodek Sportu Rekreacji i Rehabilitacji, ul. Wąska 16, 71-415 Szczecin

4 Pomorski Uniwersytet Medyczny w Szczecinie, Klinika Neonatologii Katedry Położnictwa i Ginekologii, ul. Siedlecka 2, $72-010$ Police

$\triangle$ ciosekzaneta@gmail.com

\begin{abstract}
Introduction: Swimming is a sports discipline and physical activity which raises the human body's efficiency. Currently, in competitive sport the coach and contestants have high demands to meet. The competitors are trained at the highest level to achieve the expected effects.

The aim of the study was to determine the body composition of participants during the tapering period prior to the Main Polish Championship in Swimming in 2016.

Materials and methods: The examination took place during the tapering period prior to the Main Polish Championship in Swimming in Szczecin in 2016. The study involved 34 participants -7 female aged $16-19$ (mean 18.2) and 27 male aged 16-24 (mean 18.8). The research consisted of 6 measurements of body composition taken with a Tanita BC-420 MA analyzer. In the statistical analysis we used the values of bone mass (BM), mass
\end{abstract}

of body fat, free fat mass (FFM), muscle mass (MM), total body water, and body mass index (BMI).

Results: The analysis of the content of fat mass in the examined swimmers before the first training period revealed a statically significant reduction in the third $(p=0.038)$, fourth $(p=0.038)$ and sixth $(\mathrm{p}<0.001)$ weeks of training. The average BMI reduced in swimmers before the sixth training period compared to the first training period $(p=0.036)$. There were no statistically significant differences in the content of FFM, MM, or BM in the body between each training period.

Conclusions: Direct preparation before taking part in the Polish Championship in Swimming does not influence changes in the content of FFM, MM, or BM in swimmers. Reduction was only found in the content of fat mass after six weeks of training, which lead to a decrease in the BMI of the athletes.

Keywords: swimming; body composition analysis; Polish Championships in Swimming.

\begin{abstract}
ABSTRAKT
Wstęp: Pływanie to dyscyplina sportowa oraz forma aktywności fizycznej, która znacząco podnosi wydolność fizyczną organizmu. W obecnych czasach sport wyczynowy stawia przed trenerami i zawodnikami wysokie wymagania. Żeby uzyskać oczekiwane efekty, zawodnicy szkoleni są na najwyższym poziomie.

Celem badań była analiza składu ciała zawodników w trakcie bezpośredniego przygotowania startowego do Głównych Mistrzostw Polski w Pływaniu w 2016 r.

Materiały i metody: Badania wykonano w trakcie bezpośredniego przygotowania startowego do Głównych Mistrzostw Polski w Pływaniu, które miały miejsce w Szczecinie w 2016 r. W badaniu wzięło udział 34 zawodników - 7 zawodniczek 16.-19. r.ż. (średnia wieku 18,2 lat) oraz 27 zawodników 16.-24. r.ż. (średnia wieku 18,8 lat). U każdego z uczestników badań przeprowadzono 6-krotną analizę składu ciała metodą bioimpedancji elektrycznej (Tanita BC-420 MA). Do analizy statystycznej jako główne dane wykorzystano pomiary masy kostnej (bone mass - BM), masy
\end{abstract}

tkanki tłuszczowej w segmentach ciała, beztłuszczowej masy ciała (free fat mass - FFM), masy tkanki mięśniowej (muscle mass - MM), całkowitej zawartości wody w organizmie oraz wskaźnika masy ciała (body mass index-BMI).

Wyniki: W analizie zawartości masy tkanki tłuszczowej badanych zawodników przed I treningiem zaobserwowano istotne statycznie obniżenie w III $(p=0,038)$, IV $(p=0,038)$ i VI $(p<0,001)$ tygodniu treningu. Średni BMI obniżył się u osób przed VI treningiem w porównaniu do treningu I $(\mathrm{p}=0,036)$. W analizie zawartości FFM, MM, BM w organizmie w poszczególnych pomiarach nie zaobserwowano różnic istotnych statystycznie.

Wnioski: Bezpośrednie przygotowanie startowe do Mistrzostw Polski w Pływaniu nie powoduje zmiany w zawartości FFM, MM, BM w organizmie zawodnika. Jedynie po 6 tygodniach treningów obniżeniu uległa zawartość masy tkanki tłuszczowej, co w konsekwencji wpływa na spadek BMI zawodników.

Słowa kluczowe: pływanie; analiza składu ciała; Mistrzostwa Polski w Pływaniu. 


\section{WSTEP}

Za sprawą ruchu sportowego w Anglii i na świecie pod koniec XIX w. pływanie stało się nie tylko umiejętnością pokonywania żywiołu, ale również dyscypliną sportową. W drugiej połowie XIX w. w Anglii powstało Amatorskie Stowarzyszenie Pływania, które skupiało osoby pragnące konkurować o miano najszybszego pływaka. Za Anglią podążyli również Szwedzi (1882 r.), Niemcy i Węgrzy (1886 r.), Francuzi (1887 r.), Holendrzy i Amerykanie (1888 r.), Włosi i Austriacy (1889 r.). W 1871 r. odbyły się pierwsze pływackie mistrzostwa Anglii, a 18 lat później zorganizowano pierwsze międzynarodowe zawody pływackie w Budapeszcie [1].

W obecnych czasach sport wyczynowy stawia przed trenerami i zawodnikami wysokie wymagania. Żeby uzyskać oczekiwane efekty, zawodnicy szkoleni są na najwyższym poziomie. Właściwie dopasowane ćwiczenia, odpowiedni dobór kryteriów selekcyjnych, logiczne kształtowanie funkcji i umiejętności oraz systematyczne monitorowanie parametrów składu ciała to kluczowe elementy powodzenia treningu [2]. Dokładnie opracowane cele realizowane przed zawodami głównymi domagają się specjalnego przygotowania przedstartowego definiowanego $\mathrm{w}$ teorii treningu jako bezpośrednie przygotowanie startowe (BPS) [3]. W Polsce najczęściej stosowany jest model trwający 5-8 tyg., który składa się z trzech etapów:

a) kumulacji - w treningu dominują głównie obciążenia o dużej objętości, ale o niskiej lub średniej intensywności treningowej,

b) intensyfikacji - obejmującej główną część BPS. Przeważają wówczas obciążenia o wysokiej intensywności, natomiast objętość treningowa ulega stopniowemu obniżeniu,

c) transformacji - rozpoczynającej się zwykle 48-godz. odpoczynkiem, który w zależności od potrzeb może być aktywny lub bierny. W tym czasie wprowadza się intensywną stymulację zabiegami odnowy biologicznej [4, 5].

Kluczowym zamiarem BPS jest wytworzenie u zawodników stanu najwyższej dyspozycji startowej do współzawodnictwa w określonych warunkach klimatycznych, w jakich będą odbywać się główne zawody sezonu [6].

Celem badań była analiza składu ciała zawodników w trakcie bezpośredniego przygotowania startowego do Głównych Mistrzostw Polski w Pływaniu w 2016 r.

\section{MATERIAŁY I METODY}

Badania wykonano w trakcie BPS do Głównych Mistrzostw Polski w Pływaniu, które miały miejsce w Szczecinie w dniach 27-30 maja 2016 r. Był to okres BPS, do realizacji którego wybrano model 6-tygodniowy. Wyróżnia się w nim trzy etapy: kumulacji (duża objętość, mała intensywność), intensyfikacji (zmniejszenie objętości, zmniejszenie przerw) i transformacji (zejście z objętości i intensywności). Dodatkowo wykonywane były na lądzie ćwiczenia gimnastyki ogólnej. Treningi odbywały się na terenie basenu olimpijskiego Szczecińskiego Domu
Sportu. Zmiana etapu następowała co 2 tygodnie. W badaniu wzięło udział 34 zawodników - 7 zawodniczek 16.-19. r.ż. (średnia wieku 18,2 lat) oraz 27 zawodników 16.-24. r.ż. (średnia wieku 18,8 lat).

Analizę składu ciała wykonano za pomocą analizatora składu ciała z pomiarem tłuszczu trzewnego marki Tanita model BC-420 MA (Japonia). Dokładność pomiaru masy ciała wynosiła 0,1 kg, a zawartości tkanki tłuszczowej 0,1\%. Aparat posiadał certyfikat CE oraz spełniał wymagania dyrektywy MDD 93/42EEC w zakresie urządzeń medycznych. Aparat ten wykorzystuje metodę pomiaru impedancji ( $50 \mathrm{~Hz}$ ) oraz system 4-elektrodowy z użyciem wbudowanych elektrod powierzchniowych przy konfiguracji noga-noga. Badania przeprowadzono 6-krotnie, z częstotliwością pomiarów raz na tydzień. Każdorazowo badania były wykonane rano, na czczo, $15 \mathrm{~min}$ przed treningiem porannym. Zawodnicy byli wysuszeni, przez co niemodyfikowana była wartość impedancji $(\Omega)$. W związku z tym, że zawodnicy byli analizowani w treningowych strojach pływackich, przyjęto wagę startową na poziomie 0,00 kg. Wysokość ciała każdego zawodnika została wcześniej zmierzona z wykorzystaniem wzrostomierza wagi lekarskiej. Do analizy statystycznej jako główne dane wykorzystano pomiary masy ciała - weight - W (kg), procentowej zawartości tkanki tłuszczowej (fat mass \% - FM\%), masy tkanki tłuszczowej - fat mass FM (kg), beztłuszczowej masy ciała - free fat mass - FFM (kg), masy tkanki mięśniowej - muscle mass - MM (kg), całkowitej zawartości wody w organizmie - total body water - TBW (kg), procentowej całkowitej zawartości wody w organizmie (total body water \% - TBW\%), masy kości - bone mass - BM (kg) oraz wskaźnika masy ciała - body mass index - BMI $\left(\mathrm{kg} / \mathrm{m}^{2}\right)$.

Analizę statystyczną przeprowadzono z użyciem elementów statystki opisowej, głównie: średniej, odchylenia standardowego, minimum i maksimum. Do oceny normalności rozkładu wykorzystano test Shapiro-Wilka. W przypadku stwierdzenia normalności rozkładu badanej zmiennej do oceny istotności statystycznej stosowano test t-Studenta dla prób zależnych lub test Wilcoxona, jeśli rozkład odbiegał od normy. Porównań między płcią dokonano przy użyciu testu t-Studenta dla prób niezależnych lub testu U Manna-Whitneya. Analizę statystyczną wykonano przy użyciu licencjonowanego programu Statistica 12 (StatSoft, Inc. Tulsa, OK, USA). Istotność statystyczna została określona przy wartości $\mathrm{p}<0,05$.

\section{WYNIKI}

W tabeli 1 przedstawiono średnie oraz odchylenia standardowe analizowanych wartości masy ciała. Zaobserwowano różnice istotne statystycznie dopiero po 5 tygodniach treningów w porównaniu do pomiaru przed rozpoczęciem I treningu $(\mathrm{p}=0,02)$. W analizie procentowej zawartości tkanki tłuszczowej badanych zawodników przed I treningiem zaobserwowano istotny statystycznie wzrost przed III $(p=0,03)$ i IV $(p=0,03)$ treningiem. Z kolei spadek procentowej zawartości tkanki tłuszczowej zaobserwowano przed treningiem VI $(p=0,001)$. Podobne wyniki uzyskano w ocenie zawartości masy tkanki 
TABELA 1. Charakterystyka opisowa badanych parametrów podczas każdego tygodnia treningu przygotowującego do Mistrzostw Polski w Pływaniu

\begin{tabular}{|c|c|c|c|c|c|c|c|c|c|c|c|c|c|c|c|}
\hline \multirow{2}{*}{ Parametry } & \multicolumn{2}{|c|}{ I trening } & \multicolumn{2}{|c|}{ II trening } & \multicolumn{2}{|c|}{ III trening } & \multicolumn{2}{|c|}{ IV trening } & \multicolumn{2}{|c|}{ V trening } & \multicolumn{2}{|c|}{ VI trening } & \multicolumn{2}{|c|}{$\begin{array}{l}\text { Różnice między } \\
\text { I a VI treningiem }\end{array}$} & \multirow{2}{*}{$\frac{\mathrm{p}}{\begin{array}{c}\text { I a VI } \\
\text { trening }\end{array}}$} \\
\hline & $\overline{\mathbf{x}}$ & SD & $\overline{\mathbf{x}}$ & SD & $\overline{\mathbf{x}}$ & SD & $\overline{\mathrm{x}}$ & SD & $\overline{\mathbf{x}}$ & SD & $\overline{\mathbf{x}}$ & SD & $\overline{\mathbf{x}}$ & SD & \\
\hline W & 73,01 & 7,25 & 72,70 & 7,19 & 73,26 & 6,91 & 73,26 & 6,91 & 73,32 & 7,11 & 73,67 & 6,96 & 0,80 & 1,46 & 0,020 \\
\hline FM\% & 11,78 & 7,31 & 13,02 & 8,67 & 12,42 & 8,07 & 12,42 & 8,07 & 12,40 & 7,47 & 11,21 & 7,26 & 0,70 & 0,86 & 0,001 \\
\hline FM & 8,47 & 4,88 & 9,34 & 6,00 & 8,22 & 4,91 & 8,22 & 4,91 & 8,96 & 5,11 & 8,16 & 5,03 & 0,61 & 0,69 & $<0,001$ \\
\hline FFM & 64,55 & 9,27 & 63,36 & 9,79 & 64,48 & 9,41 & 64,48 & 9,41 & 64,35 & 9,06 & 65,54 & 8,77 & 0,15 & 1,26 & 0,585 \\
\hline MM & 61,33 & 8,84 & 60,20 & 9,35 & 61,28 & 8,97 & 61,28 & 8,97 & 61,16 & 8,64 & 62,28 & 8,37 & 0,14 & 1,20 & 0,590 \\
\hline TBW & 45,44 & 6,08 & 44,79 & 6,48 & 45,19 & 5,99 & 45,19 & 5,99 & 45,15 & 5,95 & 45,96 & 5,71 & 0,08 & 0,98 & 0,708 \\
\hline TBW\% & 62,13 & 4,52 & 61,50 & 5,41 & 61,91 & 4,43 & 61,91 & 4,43 & 61,42 & 4,71 & 62,31 & 4,50 & $-0,55$ & 0,67 & 0,001 \\
\hline BM & 3,26 & 0,42 & 3,24 & 0,43 & 3,28 & 0,41 & 3,28 & 0,41 & 3,25 & 0,38 & 3,33 & 0,36 & 0,03 & 0,08 & 0,217 \\
\hline BMI & 22,30 & 1,10 & 22,30 & 1,35 & 22,25 & 1,22 & 22,25 & 1,22 & 22,33 & 1,22 & 22,16 & 1,30 & 0,23 & 0,48 & 0,036 \\
\hline
\end{tabular}

X - średnia; SD - odchylenie standardowe; p - istotność statystyczna; W - masa ciała (kg); FM\% - procentowa zawartość tkanki tłuszczowej; FM - masa tkanki tłuszczowej (kg); FFM - beztłuszczowa masa ciała (kg); MM - masa tkanki mięśniowej (kg); TBW - całkowita zawartość wody w organizmie (kg); TBW\% - procentowa całkowita zawartość wody w organizmie (\%); BM - masa kości (kg); BMI - wskaźnik masy ciała

tłuszczowej. Istotne statycznie obniżenie zaobserwowano w III $(p=0,038)$, IV $(p=0,038)$ i VI $(p<0,001)$ tygodniu treningu $\mathrm{w}$ porównaniu do oceny sprzed I treningu. $\mathrm{W}$ analizie zawartości FFM, MM, BM oraz TBW w poszczególnych treningach nie zaobserwowano różnic istotnych statystycznie. Jedynie TBW\% różniła się istotnie pomiędzy pierwszym a ostatnim pomiarem $(\mathrm{p}=0,001)$. Średni BMI obniżył się u osób przed VI treningiem w porównaniu do pierwszego pomiaru $(\mathrm{p}=0,036)$.

W tabeli 2 przedstawiono wyniki wybranych parametrów w każdym tygodniu treningu w zależności od płci. Podczas pomiarów masy ciała zaobserwowano istotne różnice $\mathrm{w}$ zależności od płci podczas I ( $p=0,021)$, III ( $p=0,009), V(p=0,015)$ oraz VI ( $p=0,041)$ treningu. Wyższe wartości masy ciała zaobserwowano u mężczyzn. Z kolei u kobiet wykazano większą procentową zawartość tkanki tłuszczowej oraz masę tkanki tłuszczowej przed każdorazowym treningiem ( $\mathrm{p}<0,001)$. W poszczególnych pomiarach zaobserwowano u kobiet mniejsze wartości FFM $(p<0,001)$, MM $(p<0,001)$ oraz BM $(p=0,002)$. Różnice w TBW oraz TBW\% w zależności od płci zaobserwowano podczas każdego $\mathrm{z}$ pomiarów $(\mathrm{p}<0,001)$. Mężczyźni wykazali wyższe średnie wartości niż kobiety.

\section{DYSKUSJA}

Bezpośrednie przygotowanie startowe, jakie przeprowadzone zostało przed Mistrzostwami Polski w Pływaniu w ciągu 6 poprzedzających tygodni, obejmowało etapy treningowe: kumulacji, intensyfikacji i transformacji. Jest to model najczęściej spotykany i z powodzeniem stosowany

TABELA 2. Statystyka opisowa wybranych parametrów analizy składu ciała z podziałem na płeć sportowców

\begin{tabular}{|c|c|c|c|c|c|c|c|c|c|c|}
\hline \multirow{2}{*}{\multicolumn{2}{|c|}{ Parametry }} & \multicolumn{4}{|c|}{ Kobiety } & \multicolumn{4}{|c|}{ Mężczyźni } & \multirow{2}{*}{$\mathrm{p}$} \\
\hline & & $\overline{\mathbf{x}}$ & SD & $\min$. & maks. & $\overline{\mathbf{x}}$ & SD & $\min$. & maks. & \\
\hline \multirow{7}{*}{ I trening } & W & 66,54 & 5,12 & 61,10 & 73,40 & 74,55 & 6,90 & 61,30 & 91,80 & 0,021 \\
\hline & FM & 17,32 & 3,51 & 14,40 & 21,20 & 6,36 & 1,73 & 3,60 & 10,60 & $<0,001$ \\
\hline & FFM & 49,22 & 2,21 & 46,70 & 52,30 & 68,20 & 5,81 & 57,60 & 84,00 & $<0,001$ \\
\hline & TBW & 35,64 & 1,75 & 33,50 & 38,30 & 47,78 & 3,98 & 39,80 & 57,50 & $<0,001$ \\
\hline & TBW\% & 53,66 & 1,89 & 51,10 & 55,40 & 64,15 & 1,62 & 60,90 & 66,30 & $<0,001$ \\
\hline & $\mathrm{BM}$ & 2,50 & 0,10 & 2,40 & 2,60 & 3,39 & 0,28 & 2,90 & 4,10 & 0,007 \\
\hline & $\mathrm{BMI}$ & 22,56 & 0,48 & 22,00 & 23,20 & 22,24 & 1,20 & 19,60 & 23,90 & 0,845 \\
\hline \multirow{8}{*}{ II trening } & W & 68,34 & 5,08 & 60,80 & 73,80 & 74,31 & 7,28 & 62,70 & 90,90 & 0,073 \\
\hline & FM\% & 26,30 & 4,47 & 20,90 & 32,40 & 8,13 & 1,94 & 3,00 & 11,10 & $<0,001$ \\
\hline & FFM & 50,20 & 2,27 & 46,50 & 52,80 & 68,21 & 6,26 & 58,40 & 83,60 & $<0,001$ \\
\hline & MM & 47,63 & 2,16 & 44,10 & 50,10 & 64,83 & 5,98 & 55,50 & 79,50 & $<0,001$ \\
\hline & TBW & 36,30 & 1,78 & 33,40 & 38,60 & 47,92 & 4,34 & 40,30 & 57,30 & $<0,001$ \\
\hline & TBW\% & 53,23 & 2,46 & 49,40 & 56,10 & 64,54 & 1,48 & 62,50 & 68,20 & $<0,001$ \\
\hline & $\mathrm{BM}$ & 2,53 & 0,12 & 2,40 & 2,60 & 3,39 & 0,30 & 2,90 & 4,10 & 0,008 \\
\hline & $\mathrm{BMI}$ & 22,56 & 1,06 & 20,80 & 24,20 & 22,20 & 1,45 & 19,30 & 24,70 & 0,750 \\
\hline
\end{tabular}




\begin{tabular}{|c|c|c|c|c|c|c|c|c|c|c|}
\hline \multirow{2}{*}{\multicolumn{2}{|c|}{ Parametry }} & \multicolumn{4}{|c|}{ Kobiety } & \multicolumn{4}{|c|}{ Mężczyźni } & \multirow{2}{*}{$p$} \\
\hline & & $\bar{x}$ & SD & $\min$. & maks. & $\overline{\mathrm{x}}$ & SD & $\min$. & maks. & \\
\hline \multirow{9}{*}{ III trening } & $W$ & 67,80 & 5,36 & 59,90 & 72,90 & 74,93 & 6,53 & 62,50 & 90,70 & 0,009 \\
\hline & FM\% & 25,56 & 4,21 & 20,10 & 30,80 & 8,04 & 1,46 & 4,80 & 11,20 & $<0,001$ \\
\hline & $\mathrm{FM}$ & 17,18 & 4,01 & 12,70 & 20,60 & 6,08 & 1,41 & 3,50 & 9,20 & $<0,001$ \\
\hline & FFM & 50,33 & 2,57 & 45,50 & 53,00 & 68,78 & 5,64 & 59,00 & 83,10 & $<0,001$ \\
\hline & MM & 47,79 & 2,43 & 43,20 & 50,30 & 65,39 & 5,36 & 56,00 & 79,00 & $<0,001$ \\
\hline & TBW & 36,39 & 2,09 & 32,70 & 38,80 & 47,87 & 3,72 & 41,00 & 56,90 & $<0,001$ \\
\hline & TBW\% & 55,20 & 4,16 & 50,60 & 63,20 & 63,95 & 1,58 & 61,20 & 66,30 & $<0,001$ \\
\hline & BM & 2,58 & 0,25 & 2,30 & 2,90 & 3,42 & 0,25 & 3,00 & 4,10 & 0,002 \\
\hline & BMI & 22,61 & 0,77 & 21,70 & 23,90 & 22,14 & 1,32 & 19,90 & 24,80 & 0,364 \\
\hline \multirow{9}{*}{ IV trening } & $w$ & 67,80 & 5,36 & 59,90 & 72,90 & 74,93 & 6,53 & 62,50 & 90,70 & 0,854 \\
\hline & FM\% & 25,56 & 4,21 & 20,10 & 30,80 & 8,04 & 1,46 & 4,80 & 11,20 & $<0,001$ \\
\hline & $\mathrm{FM}$ & 17,18 & 4,01 & 12,70 & 20,60 & 6,08 & 1,41 & 3,50 & 9,20 & $<0,001$ \\
\hline & FFM & 50,33 & 2,57 & 45,50 & 53,00 & 68,78 & 5,64 & 59,00 & 83,10 & $<0,001$ \\
\hline & MM & 47,79 & 2,43 & 43,20 & 50,30 & 65,39 & 5,36 & 56,00 & 79,00 & $<0,001$ \\
\hline & TBW & 36,39 & 2,09 & 32,70 & 38,80 & 47,87 & 3,72 & 41,00 & 56,90 & $<0,001$ \\
\hline & TBW\% & 55,20 & 4,16 & 50,60 & 63,20 & 63,95 & 1,58 & 61,20 & 66,30 & $<0,001$ \\
\hline & BM & 2,58 & 0,25 & 2,30 & 2,90 & 3,42 & 0,25 & 3,00 & 4,10 & 0,002 \\
\hline & BMI & 22,61 & 0,77 & 21,70 & 23,90 & 22,14 & 1,32 & 19,90 & 24,80 & 0,364 \\
\hline \multirow{9}{*}{$V$ trening } & W & 67,96 & 4,94 & 60,50 & 72,80 & 74,88 & 6,95 & 62,90 & 91,60 & 0,015 \\
\hline & FM\% & 25,20 & 4,36 & 20,40 & 31,70 & 8,67 & 1,84 & 5,00 & 13,60 & $<0,001$ \\
\hline & $F M$ & 17,20 & 3,83 & 14,00 & 22,80 & 6,56 & 1,90 & 3,50 & 12,50 & $<0,001$ \\
\hline & FFM & 50,76 & 3,49 & 46,50 & 57,60 & 68,32 & 5,58 & 58,20 & 79,10 & $<0,001$ \\
\hline & MM & 48,19 & 3,33 & 44,10 & 54,70 & 64,95 & 5,33 & 55,30 & 75,20 & $<0,001$ \\
\hline & TBW & 36,39 & 2,14 & 33,30 & 39,90 & 47,71 & 3,84 & 40,10 & 54,70 & $<0,001$ \\
\hline & TBW\% & 53,61 & 2,13 & 50,00 & 55,40 & 63,70 & 1,95 & 57,60 & 66,70 & $<0,001$ \\
\hline & BM & 2,60 & 0,22 & 2,40 & 2,90 & 3,38 & 0,25 & 2,90 & 3,90 & 0,002 \\
\hline & BMI & 22,67 & 0,72 & 21,90 & 24,10 & 22,23 & 1,32 & 20,10 & 24,90 & 0,555 \\
\hline \multirow{9}{*}{ VI trening } & W & 68,94 & 5,14 & 60,10 & 72,40 & 74,70 & 6,96 & 61,80 & 91,30 & 0,041 \\
\hline & FM\% & 25,60 & 4,79 & 19,20 & 31,30 & 8,08 & 1,77 & 4,40 & 11,50 & $<0,001$ \\
\hline & $F M$ & 17,74 & 4,05 & 13,50 & 22,70 & 6,08 & 1,66 & 3,00 & 9,50 & $<0,001$ \\
\hline & FFM & 51,20 & 4,10 & 46,60 & 57,40 & 68,66 & 5,87 & 58,80 & 83,20 & $<0,001$ \\
\hline & MM & 48,60 & 3,90 & 44,20 & 54,50 & 65,26 & 5,60 & 55,90 & 79,10 & $<0,001$ \\
\hline & TBW & 36,88 & 2,46 & 33,40 & 39,80 & 47,93 & 4,02 & 40,60 & 56,80 & $<0,001$ \\
\hline & TBW\% & 53,58 & 2,37 & 50,30 & 56,10 & 64,21 & 1,67 & 61,40 & 67,20 & $<0,001$ \\
\hline & BM & 2,65 & 0,35 & 2,40 & 2,90 & 3,41 & 0,28 & 2,90 & 4,10 & 0,032 \\
\hline & BMI & 22,72 & 0,90 & 21,90 & 24,20 & 22,04 & 1,35 & 19,80 & 24,80 & 0,352 \\
\hline \multirow{9}{*}{$\begin{array}{l}\text { Różnice } \\
\text { między I a VI } \\
\text { treningiem }\end{array}$} & W & 1,13 & 0,15 & 1,00 & 1,30 & 0,75 & 1,58 & $-1,50$ & 3,50 & 0,514 \\
\hline & FM\% & 1,67 & 0,45 & 1,20 & 2,10 & 0,54 & 0,80 & $-0,40$ & 2,10 & 0,039 \\
\hline & $F M$ & 1,43 & 0,47 & 0,90 & 1,80 & 0,47 & 0,63 & $-0,30$ & 1,50 & 0,035 \\
\hline & FFM & $-0,30$ & 0,35 & $-0,50$ & 0,10 & 0,23 & 1,35 & $-2,90$ & 2,60 & 0,450 \\
\hline & MM & $-0,27$ & 0,32 & $-0,50$ & 0,10 & 0,21 & 1,28 & $-2,80$ & 2,40 & 0,420 \\
\hline & TBW & $-0,17$ & 0,23 & $-0,30$ & 0,10 & 0,12 & 1,05 & $-2,50$ & 2,00 & 0,615 \\
\hline & TBW\% & $-1,13$ & 0,31 & $-1,40$ & $-0,80$ & $-0,46$ & 0,67 & $-2,00$ & 0,40 & 0,078 \\
\hline & BM & 0,00 & 0,00 & 0,00 & 0,00 & 0,03 & 0,08 & $-0,10$ & 0,20 & 0,991 \\
\hline & BMI & 0,33 & 0,06 & 0,30 & 0,40 & 0,22 & 0,51 & $-0,40$ & 1,30 & 0,545 \\
\hline
\end{tabular}

X - średnia; SD - odchylenie standardowe; p - istotność statystyczna; W - masa ciała (kg); FM\% - procentowa zawartość tkanki tłuszczowej; FM - masa tkanki tłuszczowej (kg); FFM - beztłuszczowa masa ciała (kg); MM - masa tkanki mięśniowej (kg); TBW - całkowita zawartość wody w organizmie (kg); TBW\% - procentowa całkowita zawartość wody w organizmie (\%); BM - masa kości (kg); BMI - wskaźnik masy ciała 
w przygotowaniach do wszystkich zawodów w roku, ze szczególnym uwzględnieniem tych najważniejszych. Na konieczność właściwego rozplanowania treningów uwagę zawracają tacy autorzy jak Leonard czy Maglischo [7, 8].

Analiza składu ciała (bioimpedancja - BIA) pozwalająca na ocenę przygotowania startowego zawodnika dostarcza istotnych informacji. Masa ciała pływaka, jego opływowość, zanurzenie w wodzie oraz wyzwalany opór podczas pływania rzutują na osiągane wyniki [9]. Bioimpedancja jest jednak obarczona wadami, na które zwraca uwagę Segal [10]. Tak zwany stan niekontrolowany spowodowany jest ciężkimi treningami i wiąże się z odwodnieniem, przemęczeniem, zubożeniem zapasów glikogenu. Dlatego też niezwykle ważny jest dobór odpowiedniej diety i treningu oraz stała kontrola BIA w trakcie cyklu [10].

W prezentowanej pracy badania BIA zostały przeprowadzone wśród 7 kobiet o średniej wieku 18,2 lat oraz 27 mężczyzn o średniej wieku 18,8 lat trenujących przed Mistrzostwami Polski w Pływaniu w 2016 r. W wyniku analizy odnotowano istotne statystycznie zmiany u badanych zawodników pomiędzy I i VI tygodniem treningowym w zakresie W, FM i FM\%, FFM, TBW\% oraz BMI (tab. 1). W badaniach Ciosek i wsp. pływający juniorzy o średniej wieku 15,6 lat (dziewczęta) i 17,3 lat (chłopcy) uzyskali podczas 9-krotnego pomiaru BIA wyniki istotne w zakresie W, TBW oraz BMI. Badania obejmowały okres przygotowania do Mistrzostw Świata Juniorów w Dubaju w 2013 r. [11].

Analiza porównawcza BIA wykazała, iż występowały istotne statystycznie różnice pomiędzy pływakami płci męskiej i żeńskiej w zakresie większości badanych parametrów. Nie odnotowano znamiennych różnic, analizując BMI pomiędzy płciami we wszystkich sześciu pomiarach. Siders i wsp., którzy badali skład ciała pływaków sprinterów w zależności od budowy somatycznej ciała, zaobserwowali, iż FM\% u kobiet wynosił 24,4 $\pm 3,9$, a podczas sezonu pływackiego zmniejszył się o $1,1 \pm 2,8$. Nie był to jednak wynik istotny statystycznie, tak jak i wynik zmiany FM [12]. Dla porównania w prezentowanych badaniach wynosił on w I pomiarze $25,84 \pm 3,41$ oraz w VI pomiarze 25,6 $\pm 4,79$. U Siders i wsp. tylko różnica w pomiarach FFM u pływaczek była faktycznie znamienna i wynosiła 47,7 $\pm 3,7$, a jej różnica pomiędzy początkiem i końcem sezonu wynosiła $0,9 \pm 2,0$ [12]. W analizie własnych wyników parametry te kształtowały się u kobiet w I tygodniu BPS na poziomie 49,22 $\pm 2,21$ oraz w VI tygodniu 51,2 $\pm 4,1$. U mężczyzn wszystkie wyniki podanych wcześniej parametrów były istotne statystycznie. Procentowa zawartość tkanki tłuszczowej wynosiła 14,6 $\pm 3,4$ i zmniejszyła się przez cały sezon startowy o 1,0 $\pm 1,7$. Dla porównania wyniki własne kształtowały się podczas I badania na poziomie $8,44 \pm 1,82$ oraz podczas VI badania - 8,08 $\pm 1,77$. Masa tkanki tłuszczowej w wynikach badań u Siders i wsp. wynosiła 11,2 $\pm 2,7$, a zmniejszenie nastąpiło o 0,9 $\pm 1,4$, podczas gdy pływacy szczecińscy osiągnęli w I tygodniu - 6,36 $\pm 1,73$, a w VI tygodniu - 6,08 ₫1,66 [12]. Istotną różnicę u pływaków sprinterów wykazano również w zakresie FFM, która wyniosła $66,0 \pm 6,3$ i zmieniła się o 0,2 $\pm 1,6$ w ciągu sezonu. Podczas gdy $\mathrm{w}$ badaniach własnych nastąpiła niewielka zmiana pomiędzy I $(68,2 \pm 5,81)$ a VI badaniem $(68,66 \pm 5,87)$.
Quiterio i wsp. dokonali analizy budowy ciała młodych pływaków w wieku 13,3 $\pm 3,5$ u dziewcząt i 14,1 $\pm 2,7$ u chłopców. Obserwacją objęto zmiany parametrów BIA w zależności od czasu spędzonego na treningach liczonego w godzinach na tydzień. Porównanie wybranych parametrów grupy trenującej powyżej 9 godzin na tydzień z grupami trenującymi mniej (<4,5 h/tydz. oraz 4,5-8,9 h/tydz.) wykazało istotne statystycznie różnice tylko pomiędzy mniej ćwiczącymi dwoma grupa w stosunku do grupy najdłużej ćwiczącej. Najdłużej ćwicząca młodzież wykazywała znaczne różnice w TBW, FFM, BM z tendencją dodatnią. Stosunek procentowy tłuszczu do masy ciała był również istotnie różny, jednak zmniejszał się w zależności od wzrastającego tygodniowego obciążenia treningami [13].

Pyne i wsp. obserwowali zmiany zachodzące w FFM u 77 pływaków, stosując indeks masy beztłuszczowej (lean body mass index - LMI). Parametr ten - oznaczający iloraz masy ciała zawodnika i sumę pomiarów fałdów tłuszczowych - uważany jest za lepiej opisujący faktyczną masę beztłuszczową zawodnika niż standardowy parametr BIA - FFM. W wyniku przeprowadzonej przez Pyne i wsp. analizy wykazano, iż można spodziewać się dwóch momentów wyraźnych wzrostów FFM u pływających mężczyzn, czego nie zauważa się u kobiet. Podkreślono również, że LMI może być bardziej przydatny dla sportowców o budowie ciała z pewnymi odchyleniami od standardowych parametrów [14].

Utrzymywanie parametrów składu ciała jest ważnym elementem sprzyjającym uzyskaniu dobrego wyniku w sporcie. Wioślarze badani przez Klusiewicza i wsp., którzy brali udział w treningu przedolimpijskim, wykazali wzrost masy mięśniowej i zmniejszenie tkanki tłuszczowej do możliwego bezpiecznego poziomu [15]. W prezentowanych badaniach masa mięśniowa pływaków wzrosła pomiędzy I i VI badaniem, lecz nie był to wzrost istotny statystycznie. Masa tkanki tłuszczowej i jej procentowy skład istotnie się zmniejszyły.

\section{WNIOSKI}

Bezpośrednie przygotowanie startowe do Mistrzostw Polski w Pływaniu nie wpływa na zmiany w zawartości wolnej masy beztłuszczowej, masy mięśniowej oraz kostnej w organizmie zawodnika. Jedynie po 6 tygodniach treningów obniżeniu uległa zawartość masy tkanki tłuszczowej, co w konsekwencji wpływa na spadek wskaźnika masy ciała zawodników.

\section{PIŚMIENNICTWO}

1. Czabański B, Pawełko B. Historia pływania, piłki wodnej i skoków do wody. In: Czabański B, Fiłon M, editors. Elementy teorii pływania. Wrocław: AWF; 1988.

2. Siewierski M. Wielkość i struktura obciążeń treningowych pływaków najwyższej klasy w bezpośrednim przygotowaniu startowym do zawodów głów nych. Pol J Sport Tourism 2010;18:227-38.

3. Sozański H, Koch R, Sikorki R, Wojcieszak I. Bezpośrednie przygotowanie startowe a prawidłowości budowania formy sportowej. Sport Wyczyn 1987;2-3:7-18. 
4. Płatonow WN, Sozański H, editors. Optymalizacja struktury treningu sportowego. Warszawa: RCMSzKFiS; 1991.

5. Siewierski M. Participation effectiveness versus participation policy of top swimmers. Monograph on participation workload optimization. In: Moloda Sportywna Nauka Ukrainy. Lwów: L’viv State University of Physical Culture; 2007.p. 178

6. Rakowski M. Zmiany obciążeń treningowych młodych pływaków w okresie bezpośredniego przygotowania startowego. Sport Wyczyn 2005;7-8:30-4

7. Leonard J. Tailoring your approach to specific competition level. In: Colwin CM, editor. Breakthrough swimming. Illinois: Hum Kinet Champaign; 2002.

8. Maglischo EW. Swimming fastest. Illinois: Hum Kinet Champaign; 2003.

9. Łubkowska W, Troszczyński J. Poziom tkanki tłuszczowej i masy mięśniowej u szczecińskich pływaków kadry olimpijskiej, narodowej i wojewódzkiej. ARLwRW 2011;15:447-56.

10. Segal KS. Use of bioelectrical impedance analysis measurements as an evaluation for participating insports. Am J Clin Nutr 1996;64(3):469-71.
11. Ciosek Ż, Drozd A, Lubkowska A. Dynamika zmian składu ciała zawodników kadry polskich pływaków w okresie miesięcznego zgrupowania poprzedzającego Mistrzostwa świata juniorów w Dubaju w 2013 roku. Pomeranian J Life Sci 2015;61(2):232-6.

12. Siders WA, Lukaski HC, Bolonchuk WW. Relationships among swimming performance, body composition and somatotype in competitive collegiate swimmers. J Sports Med Phys Fitness 1993;33(2):166-71.

13. Quiterio AL, Carnero EA, Silva AM, Baptista F, Dardinha LB. Weekly training hours are associated with molecular and cellular body composition levels in adolescent athletes. J Sports Med Phys Fitness 2009;49:54-63.

14. Pyne DB, Anderson ME, Hopkins WG. Monitoring changes in lean mass of elite male and female swimmers. Int J Sports Physiol Perform 2006;1:14-26.

15. Klusiewicz A, Broniec J, Szczepańska B, Burkhard-Jagodzińska K. Wydolność fizyczna i skład ciała mistrzów olimpijskich w wioślarstwie (dwójka podwójna wagi lekkiej) w 6-letnim okresie szkolenia. Sport Wyczyn 2002;5-6:449-67. 